\title{
X-linked mendelian susceptibility to mycobacterial diseases
}

INSERM

\section{Source}

INSERM. (1999). Orphanet: an online rare disease and orphan drug data base. $\underline{X \text {-linked }}$ mendelian susceptibility to mycobacterial diseases. ORPHA:319605

X-linked (XR) Mendelian susceptibility to mycobacterial diseases (MSMD; see this term) describes a rare group of immunodeficiencies due to specific mutations in the inhibitor of kappa light polypeptide gene enhancer in B-cells, kinase gamma (IKBKG) or the cytochrome b-245, beta polypeptide (CYBB) genes. They are characterized by mycobacterial infections, occuring in males. 